2021

\title{
Quantitative Literacy and Guns
}

\section{William Briggs}

william.briggs@ucdenver.edu

Follow this and additional works at: https://digitalcommons.usf.edu/numeracy

Part of the Constitutional Law Commons, Criminal Law Commons, Higher Education Commons, Second Amendment Commons, and the Social and Behavioral Sciences Commons

\section{Recommended Citation}

Briggs, William. "Quantitative Literacy and Guns." Numeracy 14, Iss. 2 (2021): Article 13. DOI: https://doi.org/10.5038/1936-4660.14.2.1398 


\title{
Quantitative Literacy and Guns
}

\author{
Abstract \\ Briggs, William. 2017. How America Got Its Guns: A History of the Gun Violence Crisis; (Albuquerque, \\ University of New Mexico Press). 352 pp. Paperback: ISBN 978-0-8263-5813-4. E-book ISBN \\ 978-0-8263-5814-1.
}

Quantitative literacy and statistics are just two of many disciplines required to understand the problem of gun violence in America. However, it's also useful to appreciate their limitations in an issue that is so complex.

\section{Keywords}

quantitative literacy, guns, gun control

\section{Creative Commons License}

\section{(c) (1) (8)}

This work is licensed under a Creative Commons Attribution-Noncommercial 4.0 License

\section{Cover Page Footnote}

William Briggs is a professor emeritus at the University of Colorado at Denver. He is the author of textbooks in quantitative reasoning, statistical reasoning, calculus, problem solving, and computational methods. His work on quantitative reasoning led to a book on the history of the Second Amendment: How America Got Its Guns (University of New Mexico Press). 
It all began with a challenge that is familiar to teachers of quantitative literacy (QL) courses. I was searching for a fresh, stimulating, relevant, contemporary issue, of interest to a diverse audience of mostly liberal arts students, that illustrated mathematical or statistical thinking in action. I was probably scanning newspapers, as I usually did on such a quest, trying to find a topic that might engage my students. The place I landed was quite unexpected. It wasn't a familiar topic, but it was in the news (too much). It was important and divisive (always good for class discussions), and I thought it probably had some statistical opportunities. The topic was gun violence. So I credit QL with sending me on a remarkable decade-long investigation of the history of the Second Amendment and America's gun culture. The journey taught me some lessons that informed my teaching of QL in ways I will try to highlight below.

I might as well confess at the outset that I am a lifelong non-owner of guns, so I knew nothing about guns, the American gun culture, and our epidemic of gun violence. I started reading, and the first thing I discovered was that there are very few objective, unbiased books on the subject of guns. (QL Lesson 1: Question your sources.) Most books give away their agenda in the first ten pages, and the rest of the book is a tiresome polemical exercise in confirmation bias. At some point, I decided that a more balanced account of the subject was needed, so a book (or at least a manuscript) was born. My guiding principle throughout the project was that the story had to be accessible, engaging, impartial, and annoyingly even-handed.

Next, I convinced myself of the obvious fact that the subject of guns in America is incredibly complex. I can think of few contemporary issues that involve so many interlocking pieces: American history, constitutional law, criminology, political science, sociology, statistics, cognitive and social psychology. I am not an expert in any of these subjects. Nevertheless, I quickly came to believe that there are no easy answers to the challenge of eradicating gun violence in this country. (QL Lesson 2: Real problems are never as easy as they may appear.)

The debate over guns in America covers not only an immense spectrum of beliefs, but an equally vast spectrum of ways to justify those beliefs. On one side are the highly emotional, intuitive, gut-based, often fact-free diatribes, which exist precisely because they are effective in changing minds (on both sides of the debate). At the other extreme, are the logical, analytical, often statistical inventions, which are often less effective in changing minds and informing policy decisions. Because I was looking for material for a QL course, I was drawn to the statistical arguments for and against gun safety measures.

We teach our students that statistical studies are no better than the data on which they are based. (QL Lesson 3: Start with reliable data.) And that message is never clearer than in the case of gun data. Take the simple question, How many guns are there in America? According to one recent estimate, there are approximately 393 million guns in America-well over one per person (Small 
Arms Survey n.d.). But that number is extremely slippery because we don't register guns or license gun owners, and guns are bought, sold, stolen, traded, imported, lost, and trafficked in many unregulated ways. Needless to say, gun ownership varies significantly according to geography, gender, race and ethnicity, and economics. In the end, about all we can conclude in a gun census is that by any reasonable measure, the United States leads the world in gun ownership.

When it comes to other sorts of data-gun deaths and injuries, efficacy of laws, demographics of gun ownership, gun sales, background checks, to name just a few - the data become even more tenuous. And the data are that way, not because of nefarious manipulation of numbers (although there is plenty of room for such mischief), but more often because data are collected by many different agencies and jurisdictions, and the sharing of data is still remarkably uncoordinated (the databases for background checks is a prime example).

One of my favorite examples of "data challenges" is the industry of estimating defensive gun uses (DGUs), or the number of times in a year that guns are used in self-defense or to avert a crime. It's an important number: if the number is large, then gun rights advocates use it to support less restrictive ownership laws. If it's low (or if there are many cases of DGUs gone badly), then gun safety advocates can claim that self-defense is not a reason to own guns. Here's the state of affairs concerning this highly sought number: current estimates of DGUs range over the yawning interval of 80,000 to 2.5 million!

Related to the counting of DGUs is the more general connection between crime rates and gun ownership. A celebrated 1998 study by a respected University of Chicago econometrist looked at crime rates and gun ownership in adjacent counties that had significantly different gun laws (perhaps they were on opposite sides of a state line). The startling, headline-grabbing conclusion of the study was the title of a resulting book: More Guns, Less Crime (Lott 1998). That is, cities and counties with higher levels of gun ownership have lower crime rates. That study did not stand long without a counterattack. One salvo came from a tag-team of Yale/Stanford law faculty members who dismembered the first study, questioning its data and discrediting its statistical methods (Ayers and Donohue 2003). What ensued over several years was a dueling statistics standoff that became so technical and arcane that only the experts could follow the arguments. It became clear to me that such subtle analyses, often based on controvertible data, would never change the minds of citizens or impact gun laws and policies. (QL Lesson 4: Even when based on reliable data, statistical studies may be inconclusive or controversial.)

The book that eventually emerged from my wanderings through American history, Supreme Court decisions, firearm culture wars, and data labyrinths has two interwoven themes. One is an historical theme that traces the Second Amendment - and the laws and court cases it bred-from colonial days to the present. The other theme is the modern American gun culture that is so deeply 
embedded in our society. The book has stories and profiles of people whose lives are involved with guns: trap shooters, hunters, cowboy action shooters, practical shooters, competitive marksmen and women, collectors, gun makers, Pink Pistols (gays for gun rights), activists on both sides, academics, law enforcement officials, and legal experts. Without these two perspectives, history and culture, I believe it is impossible to understand the American gun debate, to explain how America got its guns, and to propose realistic remedies for gun violence.

As I wrote this book, I thought long and hard about how individuals of the same species could differ so profoundly in their beliefs on an issue - not a trivial subject like flavors of ice cream, but the vital issue of the ownership and use of lethal weapons. Indeed, the book has a chapter on the psychology of guns in which I tried, with the help of eminent social psychologists, to unravel this mystery.

Perhaps the most lasting lesson of my research, is the need to understand "how the other side thinks." Even if others' beliefs differ from one's own, there are of often reasonable and hidden foundations for other beliefs. The entire project gave me a fresh open-mindedness and forbearance about many divisive issues. I tried to bring this attitude into my QL classroom as we discussed issues that were both quantitative and contentious, encouraging students to exercise critical thinking skills in making decisions and to avoid clinging to hastily considered positions without convincing, factual evidence. I can't say whether I succeeded in this effort. However, I do know that there will be no progress on the crisis of gun violence in this country without such an open and tolerant outlook on all sides.

\section{Excerpts from How America Got Its Guns ${ }^{1}$}

To understand the complexity of the gun debate in America, it is essential to appreciate the diversity of gun owners. Gun ownership varies significantly by state: Wyoming leads the list with roughly 60 percent of adults owning guns and Hawaii is at the other end at about 7 percent. Ownership is almost twice as high among whites as nonwhites, and it is nearly twice as high among Republicans as Democrats. The gun ownership rate among men is higher than for women, and the total guns owned by men appreciably outnumber the total guns owned by women.

\footnotetext{
${ }^{1}$ Reprinted with permission from How America Got Its Guns by William Briggs. Copyright (C) 2017. Published by University of New Mexico Press. All rights reserved.
} 
When you think of gun owners, imagine a California housewife who participates in trapshooting events and carries a handgun for protection. Picture legions of antique gun enthusiasts who belong to their state collector associations. There are athletes training for international marksmanship competitions, some of which have Olympic status. Consider the men and women who participate in highly competitive practical shooting events. And then there are the weekend plinkers and the buddies who get together for an annual shoot on the farm. The image of gun owners as-pick your stereotype-stockpiling survivalists or raging ranchers is simply wrong. Of course, stereotyping goes both directions: Former NRA president Charlton Heston once summoned all those who "prefer the America where you can pray without feeling

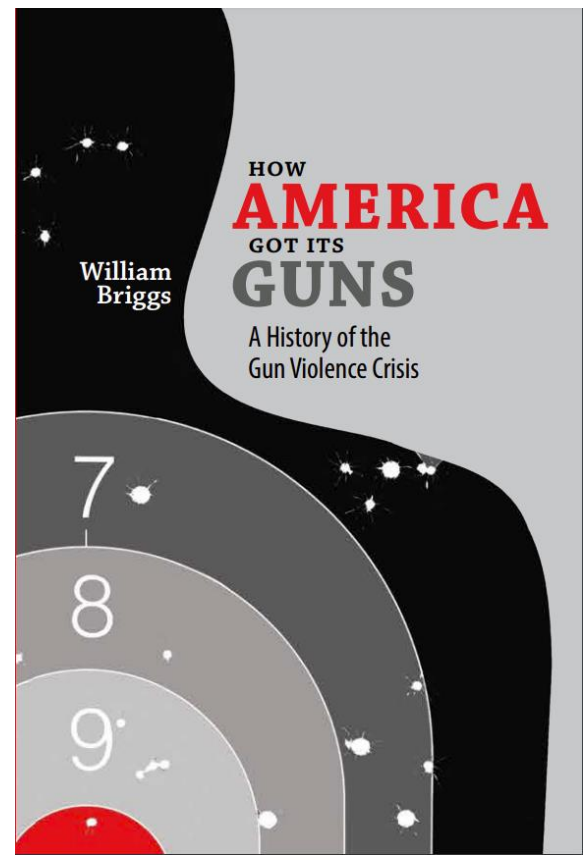

Available from University of New $\underline{\text { Mexico Press }}$ naïve, love without being kinky, sing without profanity, be white without feeling guilty, own a gun without shame" (Heston 1999) to join the culture war.

In terms of politics, race, education, and economics, gun owners do not cut a clean, homogeneous swath through our society. They form threads woven throughout the American tapestry. To understand guns in America, one must appreciate the number and diversity of gun owners and the extent to which guns have seeped - deeply and broadly - into the culture. This state of affairs only makes the gun debate more complex....

Gun-rights advocates who fear losing their guns to ATF marauders need a reality adjustment. In addition to the Second Amendment, they have recent Supreme Court decisions to protect their rights. In all the future Americas one might imagine, government-enforced mass disarmament is not a part of any of them. At the same time, gun-control advocates who dream of a gun-free America must confront their own illusions. As much as some would like to live in country cleansed of its three hundred million guns, it is unrealistic. Congress and state legislatures will ban baseball as a national pastime before it passes universal gun-confiscation laws.

For the foreseeable future, Americans will be divided on gun ownership, on their need for guns, and on their opinions of gun laws. Combine those countermanding public pressures with the glacial churning of the legislative process and the mired turning of judicial wheels, and neither a gun-free society-at one 
extreme-nor a lawless country flooded with guns - at the other extreme-is likely. The system has enough inertia to ensure that we are far more likely to regress to the mean than to find the extremes.

Progress will be made only when we bring the sidelines of the playing field back within sight of each other and work on realistic and effective measures. There is no place for either fantasies (a world without guns) or conspiracy theories (Sandy Hook was a government plot). Progress will be made only when all sides embrace compromise and when legislators listen to their constituents and resist the venal temptations of lobbyists. Progress will be made only when emotions are supervised by reason, when careless statistics are treated with caution, when we abandon false and deeply rooted stereotypes, and when we all make genuine attempts to understand opposing points of view.

\section{References}

Ayres, Ian and John Donohue. 2003. "Shooting Down the 'More Guns, Less Crime' Hypothesis.” Stanford Law Review, 55: 1193-1312. https://doi.org/10.3386/w9336

Heston, Charlton. 1999. "The Second Amendment: America's First Freedom." In Guns in America: A Reader, edited by Jan Dizard, Robert Muth, and Stephen Andrews. New York: New York University Press.

Lott, John R. 1998. More Guns, Less Crime: Understanding Crime and Gun Control Laws. Chicago: University of Chicago Press.

Small Arms Survey. n.d.

http://www.smallarmssurvey.org/fileadmin/docs/Weapons_and_Markets/T ools/Firearms_holdings/SAS-Press-release-global-firearms-holdings.pdf, retrieved May 16, 2021 